\title{
Tourism and Development: De/Constructing Discourse
}

\author{
Roshan Thapa*
}

\begin{abstract}
This article is an outgrowth of an odyssey of more than a decade to the very popular touristic destinations of Nepal, namely Ghale Gaon, Sirubari and Bandipur, and disciplinarily synergetic in my act of knowing and representing- the objectivities and the subjectivities emerging in tourist-host interaction, the public discourses, and the ways these have shaped these destinations today-my primary concern in this article. Today, these destinations, which would perhaps remain virgin, development and otherwise, are at threshold, vividly manifesting array of changes in every spheres of living in with their adherence to villagetourism in the name of development per se modernization, the camelian evolution if not reinstate on time with pragmatic tourism paradigm to my anticipation these destination will not thrive to attack tourists as of today and consequently thwart development in true sense With this conscientization, by focusing on the effects of tourism and new ways of sensing tourism and development this article proposes an alternative episteme in tourism and development analysis with special reference of these destinations In my attempt to do justice to the era to which I belong, as a devotee of post-modernism centripetal to undertaking this task were the postulates of social constructivism and "(N)One Paradigmatic Research Design", at my disposal. I am hopeful that this paper contributes to the deficit of knowledge in relating concepts and theories to what I termed as anthropic development.
\end{abstract}

Keywords: anthropic development, discourse, pragmatic paradigm

\section{Introduction}

It was then...

Just because I don't know

to fasten the wrapper in/of traditional costume

to cut grass in the hills

You cannot say that I am not Nepali

* Dr. Roshan Thapa is a Research and Development Consultant, Adjunct Faculty KU and St. Xavier's College. Email:drrosh_ku@hotmail.com. 


\author{
I like kazol and tika \\ But I am not habituated to put them \\ Nor am I to cow-grazing and transplantation \\ and have experience of up-down roads \\ Yet I love my country \\ Even though I cannot sing folk songs \\ I know probing them \\ I can manage dancing in them \\ Hats off to all the rituals and culture \\ I am a modern girl with my won pride...
}

I have inaugurated (my doing of) this paper with this popular song to convey two ideas and frame the design for this paper. My first point is obvious one, even if it is not made explicit: in spite of the abstraction and frequent recourse to qualitative research, I wish to assume somewhat holy position from the hitherto available traditions of qualitative research, that this nodal experiences is intensely personal objectify my standpoint; nevertheless, the song must be thought of as a constant background to all that follows. Secondly, I want use this song to suggest that it stands as an allegory of the discursive polemics, about the emerging form of these touristic destinations, Bandipur, Sirubari and Ghale Gaon. This is a complex point, not meant to imply that incidents I narrate are actually personal; rather common to and the representative of these destinations as a whole and well drenched with core values of transformative research design gaining its currency in academia at present.

Ever since 2005, I am into the tourism field professionally as a practitioner, I have been privileged to visit these three destinations sporadically, at least once in every year, with the natives of different nations that not only has it provided me an opportunity to be familiar with rhetoric and the realities of these destinations but also, with the other feathers that decor my hat-social work and development anthropology which have taught me the lesson of post development, to scrutinize hand -in -hand how anthropic marriage between tourism and development be best arranged to holistically benefit these destinations. Consequently, this paper came into existence.

Needless to argue here that, tourism for development and vice-versa, a timehonored fact as what flesh is to nail, overtime has marched ahead with many contextual discourses of connotative variations. These destinations reminded me of a popular song by Bob Dylan- "Tangle up in the Blue": when a single entity reflects paradoxes people tangle up in the blue. On the one hand, tourism in these destinations via home-stay, if viewed from the perspective of locality development model of social work and development anthropology which asserts that community change can best be brought about through broad participation of a wide spectrum of spectrum of people at the local community level (Zastrow, 2009), seemed developed as par with 
the blue-prints of later trends in development. While on the hand, the outcome of these efforts in these destinations legitimates departure towards modernization and westernization. Something like entangled in a tug-of-war between traditional and modern culture, these destination today are at threshold, like a bride leaving her natal home, from traditional towards modernization.

Given this glimpse, I am driven with dual objectives in my doing: first, to furnish social objectivities and subjectivities that emerged within tourist-host interaction and the manner these have shaped these destinations today and, second, to propose a contextual alternative episteme to tourism and development. I am with Marx that it is not the consciousness of human that creates their being; rather on the contrary their being creates their consciousness (in, Francise, 2001). It is for this reason; centripetal to my excavation I have endorsed discourses analysis, more specifically related to tourism and development, to extract meaning within the aims of this paper. I am with Long (2001) that discourse here refers to a set of meanings embodied in metaphors, representations, images, narratives, and statements that advance a particular version of the truth about objects, persons, events, and the relations between them (in Gee, 2005). These popular culture, thus, are vehicle through which culture travels and the study of these helps us to know about the culture of that society (Thapa, 2016).

I am of opinion that despite the significant attention paid by tourism and development academics and practitioners to tourism and development in recent years, there has been a consistent failure within the literature to relate the concept to the theory to anthropic development (Acharya \&Halpenny, 2017; Regmi\& Walter, 2016), legitimates the rationality of doing this paper with its promise to contribute to this deficit of knowledge with special reference to these destinations so selected to draw analogical proposition: Gale Gaon and Sirubari being the pioneer and considered as relatively successful project and while Bandipur is at the state of developing.

In an organization of this paper, the layout of this paper is so constructed asa portrayal of transformative venture that "(N)One Paradigmatic Research Design" (Thapa, 2016) advocates: an attempt of in Davis's sense "Broader Crossing" (Davis, 2010) with what Jipson and Paley called "A Practice of No Practice"(Jipson\& Paley, 2013), in my attempt of knowing and representing. In what follows the notion of Spry (2001)- "Being There" and "Being Here". I begin the narration of my ontology and epistemology which is derived from my position as in "Being There", meaning my situatedness in those destinations in anthropological way with double face, as a researcher and a tourist too. Adjacently under the section "Being There" I illuminate light on my postcard experiences to narrate now and then of these destinations. From my position as in "Being Here"-a scholar among scholars, I move on drawing analogy with available literature and place my doing of this paper at its (temporary) resting 
point at this detour with the derivation of pragmatic tourism and development and conclusion with possible recommendations.

\section{Ontology and Epistemology}

The present era, to which I currently belong, scholars like Crook, Pakulski, and Waters (1992) typified as post-culture wherein modern cultures characterized by mass production, mass consumers, huge cities, material and technical advancement, differentiation, urbanization, industrialization, rationalization, standardized production, centralization, and bureaucratization are on the decline and flexibility, diversity, dedifferentiation, mobility, communication, decentralization, and internationalization are on the rise (Lash \&Urry, 1994) asks us to wear discrete lenses of transformative fragrance to nuance any contemporary issues. Accordingly, this volatility intrinsic to realities has made a transformative researcher with distinct ontological and epistemological standpoint.

My perspective is that: tourism has experienced many transformations in time and space parallel with many social changes that have appeared during the shift from the modern to the postmodern culture. The tourism market has been expanding and tourists have become more demanding and lickerish and there has been an increase in the creation of new tourist services that put an emphasis on emotions and experience (Richards, 2001). Contrary to the traditional conceptualization of tourism as mass tourism typical to that emerged as the aftermaths of the Industrial Revolution and the processes of industrialization, urbanization, and technical and technological developments of society evolving since the beginning of the 19th century, the phenomenon of contemporary tourism includes different types and sorts of holidays, means of transport, destinations, and activities, which, depending on the context of time, gain or lose popularity. On one hand and owing to its dynamics, tourism offers new and exciting destinations, new arrangements, and new ways of travel. While, on the other, it requires new organizational forms, new resources, and new strategies of development. In such a context, I am of opinion that the initial narrow conceptualization of the so called functionalist paradigm, permeated tourism theory and research and it has been held responsible for the creation of tourist typologies (Smith, 2005), whose main purpose was the categorization and classification of tourists on the basis of some of their traits, motivations, activities and experiences while travelling, is inept to serve the purpose of this paper to operationalize tourism and development pragmatically. My perspective is that the development of the tourism industry, in the present era, should be regarded in the context of the development of new forms of tourist consumption and the convergence between the patterns of consumption, leisure, and tourism that this theoretical shift in post modernity requires a shift away from the typologically rigid and narrow modernist theoretical framework towards more flexible conceptualizations (Wearing, Stevenson, \& Young, 2010). The 
abandonment of tourist typologies, taking into consideration the fact that tourists are not passive consumers, the shift of attention towards the existential authenticity, and the admittance that tourism is a multisensory and physical experience bear witness to the recent theoretical turn in the study of the tourism. Such a shift of opinion has been closely linked with the emergence of the postmodern thought (Franklin, 2003; Uriely, 2005).

\section{Ways of Knowing and Representing}

In my understanding of knowledge is evolved around a rigorous and individual quest for meaning making that accepting research methodologies, as they existed and were available to me, is like cutting wings from my intellectual thought. Accordingly, in my doing of this paper discourse analysis is integrated with this theoretical assumption: discourse analysis is theory and methodology in one (Gee 2005; Jørgensen \& Phillips 2002; Phillips \& Hardy, 2002). Continuing with what has been slightly shared above, discourse denotes a shared way of presenting and perceiving the world among certain people and discourse enables people to give meaning to certain objects or phenomenon and thereby to perceive reality as certain truths in coherent stories (Dryzek 1997).In a sense, discourse does not represent social reality but constructs social reality and language as a media for narration plays a fundamental role in discourse (Gee 2005). With this constructive characteristic, discourse may be defined as "language plus other stuff" (Gee 2005, p. 26) or, more precisely, linguistic text plus social context such as the thinking of the actors and the power relations among the actors (Alba-Juez 2009).In align with this notion, I have adopted the social constructionists view that one way to access social reality is through semiotic systems in which meaning is produced based on links among different signs in different contexts so discourses change go together with social change (Jorgensen \& Phillips 2002). Hence, the value of discourse studies lies in understanding social practice and social change through analyzing discourse. I assume that language, as an important semiotic system, forms discourses within various contexts, thereby constructing social reality (Burr, 2003).

Whilst doing so, I have selected two songs, common to all three destinations, which are placed under the custody of epistemic metaphors of holistic meaning making and knowing as envisioning (Luitel, 2016).Recalling of past- that's how it begun with memory work as a method and a practice of unearthing and making public untold stories. As Kuhn, I am of opinion that memory work can create new understanding of both past and present and presents new possibilities for enriching our understanding how we construct our own histories through memory, even how we position ourselves within wider, more public, and histories (in Thapa, 2016 ).Above all, because of my orientation and specialization in autoethnography, that in the era of post-modernist, I cannot detach myself being close to the notion of knowing as 
autoperformivity (Alexander, 2005). I have portrayed my "self" as being confessing, critical, uncertain, certain, relative and futuristic, which I believe the best qualifies my doing of qualitative research and also cleanse post-modernist quest regarding crisis of representation (Denzin \& Lincoln, 2005).Thus, it should not surprise my potential readers when auto/ethnographic fragrances are elsewhere in my doing. Armed by the host of representational means- textual and non-textual genres- avail at the disposal of “(N)One Paradigmatic Research Design", as a transformative researcher I have employed narrative, dialogical, metaphorical and poetic logics and genres so as to illuminate my inquiry agendas as opposed to positivist methods of writing as creating detached and impersonalized text. Unlike the conventional Greco-Western definition of logics as basis for ascertaining absolute truth, I have employed logics for manifold use: as strategies to persuade audiences and readers; as a framework of making meanings in context; and as a tool for communicating aides as incisively as possible (Bagni, 2008).

\section{Being There}

Dancing like a pheasant

Smiling like a mountain

I am daughter of Nepal.

Colors filled by nature

I am a gorgeous "white"

Magic spreads here

upon the veil opening

Happiness prevails in all

upon speaking with smile

Dancing like a pheasant ......

Colors filled by nature

I am beautiful "white"

Even bud of the flow blossoms

upon the smile

Water cascade sings

Peacock dances

upon the smiles

upon the dances

Dancing like a pheasant ......

Colors filled by nature

I am beautiful "white"

No doubt, analogical to the portrayal in the above song, Sirubari, Ghale Gaon and Bandipur, are exotic pristine villages endowed with an unparalleled cultural and natural opulence-a self-content daughter always smiling like an unwavering 
mountains and dancing like a happy pheasant, and who is aware of all hospitable services to guests. I have no comments on how the people of these destinations had epitomized their place via this song (during the cultural show). My concern here is: What has caused ripples in this still water? What has made them add an adjective beautiful as synonymous to "white"- not to "black"? At this moment, I take a small pause leaving the ball in the court of my potential readers.

Ever since 2005 I have been in tourism field professionally, I am with euphoria to experience the fascinating narrations that unveil these destinations. This longingly cherished dream finally came into existence with my visit to Ghale Goan with a group of Italian people in the same year. The Ghale Gaon as people have personified

It's the place

Where I was born and brought up

Where I cut grass and collected fodders

Dear to me than the heaven,

My place Ghale Gaun

As, Nidung river flowing

Mountains glowing

Rhododendron blossoming

The face of my Ghale Gaon glowing

Cool breeze from/of snow

And now the motor is arriving

The water of Sakunya is tasty

The temple of UttarKanya is beautiful

Rodhi, Ghatu and Sorathi....our Gurung Culture

Wild bees

Sheep sheds

Where do I go to find them?

An ideal village in Asia

My Ghale Village

Identified with century-old history

Considers guests as gods

Weave and entangle them in love

Such a beautiful tea garden

Where do/can I go leaving this place?

Though I am mortal... May this place be immortal.

My Ghale Gaon

Where I was born and brought up

The lavas of enticement and appellation kept suppressed within me for long so erupted then that the journey of five hours trekking, one of its first kind experience 
in my life, from Besisahar to Ghale Gaon was made with no realization. Customary welcome preparation at its neck with a musical band by Dalits and a row of eagerly waiting Gurung women with garland and other worshiping materials at hand, bears the testimony of the fact that they had left no stone unturned to translate their consideration "Guests are God" into practice. I was so enthralled that I could feel lungs blowing and blood vessels running differently and goose bump around my body then and wordless here to narrate the holy-hospitality bestowed from within.

Namaste Sir, Warm welcome to Ghale Gaon... might have so difficult to walk all the way. may be because you people are not habituated. What to do sir...roads of village... an unfinished agenda of government to build... when will this remote village have a chance of experiencing development...only after I die

Only after I die...the people seemed so pessimist with the retarded development process of the government but happy with what they had been doing with tourism. Swathe with a garland of local flowers, white tika on the forehead and having a little of homely brewed alcohol as customary welcome drink we were departed to separate individual house-hold for rest. After a short walk in a stone-paved alley with dunks and urine of cattle's scattered around, I reached my home. Posters of deities and family members pasted against the walls, chicken under a bamboo basket, a water tap and a small garden in front of the courtyard and a cattle shed adjacent to the house, typical to remote village in general were so captivating. I could see a disc-antenna on the tin-roof replacing traditional stone-roof of that village, as if teasing authenticity and indigenousness of Ghale Gaon, the intensity of which was noticed multiplying in every later visits.

Sir, this is your room and the toilet is there. Room of village house is like this. It may not be as your room in Kathmandu. Please manage. You must be hungry with tiresome journey. Please, wash your hands for the dinner. We can continue talking during the dinner, can't we? We also have to attend the Gurung cultural show.

The kitchen with cocktail possessions of electronic gadgets and other roomdecorative items tied up with a typical Ghale tradition and a small girl reciting English vocabularies all were so captivating.

How is the food? My granddaughter is very studious. I want this girl be a big person like you reading a lot. His father has said that he will take her with them to Besisahar for her higher study in private schools. Government school here cannot teach English to children. Sir, please have food. It seemed that my talking made you forget to eat. I hope the food commensurate with your taste. Sir if you don't like homely brewed alcohol, I can purchase beer, vodka or whisky of your choice. We have a shop nearby where we get almost everything that you get in Kathmandu. These "Khaire" (meant for white and brown foreigners) are weird creator. They use mostly paper in toilet. They shamelessly 
hug and kiss. However, they like our village enjoy the foods we serve and some ask us if we could make exotic food. It seems that they are scared to try our food.

Similarly, with every later visit, I noticed the authentic staple foods have been replaced by imported food items. Surprisingly, I was frequently served meat of hybrid chicken, rice and other vegetables which they think tourists like and have been making their life easier. My quest for authenticity was bitterly battered. During the dinner and also include informal conversation with people, the conversation scattered on various issues that helped me prepare the ethnography of the Gurung, which is here deliberately excluded here as it lies out of the concern of this paper.

Similarly, my experience in Sirubari is not significantly different than that of Ghale Gaon. Except Sirubari being much cleaner, relatively educated and high in number of foreign employment, both share almost all thing in common, perhaps one reason both are Gurung community of north-west Nepal and for another reason Ghale Gaon being the replica of Sirubari

Having heard and anticipating that Ghale Gaon could be fertile ground for homestay tourism as in case of Sirubari to benefit local community and to add a brick on development, after a five day visit to Sirubari we have started home-stay program here in Ghale Gaon since 2005.

Unlike, Sirubari and Ghale Gaon where Home-stay program seemed working well in their own efforts despite negligible support from the government, the story of Bandipur is so bitter. "Why does the travel agency, keep their guests in Hotels, not in home-stay when there are plenty of homes with the board of home-stay?" I was frequently battered by this question for one reason I am against elitism under whose supervision tourism in Nepal prospering. I hold the views that, if Mt. Everest, Gautama Buddha and other cultural and natural heritage for which tourists visit Nepal belong Nepal as a whole, tourism should be viable to benefit all Nepalese in a fullest possible way. Contemplating that the home-stay owner would cleanse my quest, I rambled around the village for the same.

This privately owned home-stay but there is one community owned group too. The spillover from the hotel and tourist who-like to accommodate with local family come to stay with us. We have no connection with any travel agencies. Tourists roam around personally and come back to stay. We tell them about the famous tourist. We do not have any fixed itinerary and programs. This is a menu for tourist. Tourist can order food of their choice and the prices are accordingly set. Upon the request we also prepare and deliver any kind of exotic foods.

Home-stay program in Bandipur seemed as sprouting out of people's identification of alluring potential of home-stay to attack tourists in Nepal ascending day by day. 
Similarly, the very fact in its existence as heteronymous society, composed of the indigenous Magar and the migrated groups as the Newars after Kathmandu valley had been conquered by Prithivi Narayan Shah in 1768, and people of different caste as it grew into a trading hub following the Newar's arrival(Blaikie, Cemeron\& Seddon, 1980), as per my observation, has been thwarting Bandipurian's attempt to consolidate as in case of Sirubari and Ghale Gaon for a collaborative effort to promote home-stay program.

What to do sir. Everyone is blowing their own trumpet. There is no single tuning among the providers of home-stay. There are very unhealthy competitions and no authority to check it. However, home-stay program has helped us economically. Awareness level on education and health has been increasing with tourism. Women group become active. There have been initiatives to clean and preserve natural and cultural heritage.

This reminds me the plight of Dalits as in case of Sirubari and Ghale Gaon in making home-stay program an inclusive project of development though the management showed an integration of different caste.

We are considered as untouchable. The Gurung do not let us enter inside their house. They call us to play music and carry the luggage when the guest comes. We, untouchables, are not included in home-stay program to accommodate guests

I am with Acharya and Halpenny (2017) that, ideally, in community-based enterprising contexts, many domains of potential deprivation that create exclusion are subdued and different ways that promote inclusion are encouraged. I also agree with Sloan, Legrand, and Simons-Kaufmann (2014) that social progressions such as improved quality of life, increased income capacities, poverty decline, and better education of indigenous communities by community based hospitality projects' social inclusive approaches. But I doubt whether the statement like of one politician of Ghale Gaon"this [homestay] has emerged based on goals of community's overall wellbeing by bringing the community members towards an equitable benefit sharing system" (in Acharya \& Halpenny, 2017) is a commitment or a statement of emotion. I am of opinion that inclusion is still a glossy development jargon requires revisiting with the perspectives of gender, location caste and class differences.

\section{Emerging Identity}

By emerging identity, I mean the newer form that these destinations are acquiring with tourist-host interaction in the name of development. When tourists and locals come together, this cross-cultural interactions cue "live performances"- both the host and the guests have the opportunity not only to glimpse how others live, but also to reflect on their own lives through the eyes of others. The intrinsic meaning of the inaugural song, paradoxical in its content with the patriotism as revealed via above 
songs, epitomizes the rhetoric and a reality of these destinations today. The connotative definition of modernization per se development, especially among youth, is that to be modern is to unfollow the century-old cherished traditions, customs and culture. In a sense culture is viewed as detrimental to development, thereby leaving ground for acculturation, which in their context commensurate with this Nepali legend:

...God has once thought of creating the most beautiful creature out of assembling the most beautiful part of each animal it has created thus far, eyes like a deer, waist like a bee, and neck like a giraffe and so on. Finally a very disappointing creature is created, the camel...

At its natal-state, as epitomized by Kunwar (2000) in his book The Himalayan Heritage and Bista (1972) in his book The People of Nepal intrinsically people (Gurung, Magar and Newar) of these destinations are adamantly rural at heart. The ways of living was conventionalized into a coherent system. Behavior was traditional, uncritical and personal. Kinship, its relationship and institution were typical categories of experience and the familial group is the central unit action. I am now in position to state that as their interaction with tourism is spreading its wing far and wide, broad spectrum of perception developed within this interaction has incurred people of these destination in camel-creation because of xenocentrism developed in the line of "West is best" notion. From classical development perspectives all three destinations enjoy tourism: tourism has provided the economic stimulus to allow for diversification of employment and income potential, and develop resources within the community, at the same time a kind of what Kunwar (2010) called cocktail or Coca-Cola culture has been erecting.

These destinations as a whole displays multiplicity of institutional changes: in family sphere, the extended kinship unit has been losing its pervasiveness; in religious sphere, secularized belief system has replaced traditionalistic religion; in the stratification sphere, geographical and social mobility has tended to lose fixed, ascribed, , hierarchical system; in the educational sphere, changes in attitude regarding girls and English. The positive impacts are related more to the materialistic well-being, rather than to the happiness of a community or tourist while the negative impacts are the effects that are caused, in most cases, with detrimental impacts to the social and cultural area, as well as the natural environment. I wish to legitimate my arguments with the discussion of these three broader effects

\section{Demonstrative Effect}

Tourists demonstrate a way of life seems desirable, and xenocentrism being in the blood of these destinations this is emulated to varying extents. Awareness about heath, education, social entrepreneurship infrastructure development, and preservation of natural and cultural heritage is no doubt benefitting these destinations. 
There is no hospital. It costs around sis-seven thousand to take to city hospital. There is lack of human resource to carry the sick and in case if something happens to guests. The nearest health-post is about half-an-hour distance and has no good health facilities.

We have problem of water supply. Our guests are particular about their hygiene. They need a lot of water and take bath twice a day.

We need different trainings, like cooking as some guests do not like local foods and vegetable farming. What is the benefit of declaring Ghale Gaon as an ideal village in Asia, when there is no support from the government? The government should also help us. Government should us grants and subsidies with provision of loan. We can generate employment here we can retain youths from going abroad.

I earn about fifteen thousand per month. I use the money for household work and use the saving to replace stone roof with tin as we do not have mason. It has made us independent. I do not have to wait my son and husband to send money from abroad.

But what is devastating therein is tourism viable in instilling capitalism via cultural dependency under which scenario local economy improved but people forgetting their past or "losing their culture" as they adopt the new lifestyles and ways of being they learn from outsiders(Erisman, 1983). There is the massive influx of foreign goods, people, and ideas to these destinations has a negative impact, which, ultimately, eroding people's self-esteem as they have begun to act and think like tourists, whom they perceive as superior in every way. I am with Reed (1995) that commodities have been a corruptive force among these indigenous peoples pulling "deeper into the dark vortex of commercial activities and spewing them out on the other side of the ethnic boundary into the harsh light of national societies and the international economy" (p. 137).

The other house replaced its roof with tin, purchased many electronic gadgets. My little granddaughter demands the same. It is the question of status. If I ask my son to go to the country of these foreigners will bring money for the same

I have been involved in home-stay program for seventeen years. There are only uneducated people in village. All educated go to city for work and better opportunities. People with money migrate from the village.

I have now stopped running home-stay. I am sixty-nine years old. I am alone at home and difficult to run the program. My elder son and daughter-in-law stays in Besisahar for better earning and their children's education and the younger son is apathetic towards home-stay and other agricultural work. Neither can I go up to Besisahar to purchase things nor can I grow here.

The life of young generation portrays a very discrete culture; it has become sophisticated, easy and fast. Collectivism, spirituality, social cohesion, the nucleus 
of typical Gurung and Magar families, all has been losing its ground towards individualism and materialism. Youngsters are becoming tempocentric and materialistic. Exotic fast food items fascinate people. Commensality is almost forgotten. However, at another level, perception towards gender relation in terms of gender mobility, education, division labor has introduced significant changes in their lives. People's shyness and hesitation are being gradually obliterated and they are empowered with the knowledge of national and international issues. What is noteworthy herein too is that an ever increasing validation of private education as source of symbolic capital, giving those who possessed it claims to superior positions and status has given birth to new division and new forms of disdain (in the words of Bourdieu "Symbolic Violence"). Like a double-edged sword that cuts both ways, tourism via one of its positive impacts awareness in education too has been adding a fuel to modernization, getting schooling a state instrument in disseminating sociopolitical agenda which include rejection of socio-cultural practices and knowledge system as well as homogenization of the society molded as per the elites culture system Skinner and Holland (2009).

\section{Commodification of Culture}

Whether one of the central attractions, especially of Ghale Gaon and Sirubari, the cultural show comprising Ghatu, Bells, Krishna Charitra, Lama, Ghabre, Jhyaure and Sorathi dances performed as vehicle to satisfy both type post modern tourist under the consideration of this paper, "simulational" postmodern tourism that follows notion of "pseudo-events" and the "other" postmodern tourism that follows MacCannell's (1976) quest for authenticity is characterized by the multiplicity of tourist motivations, experiences, and environments, has caused the Commodification of culture and hence packaging and selling it for consumption. This has doubtlessly reinvigorated interest in lost arts and skills and foster community cohesion. While on the other hand, it is through this attaching of economic value to heritage it has been losing its intrinsic meaning, thereby the emergence of a culture which is no longer authentic.

\section{Acculturation}

I am with Schmidt, (1989) that long the development processes and through host-guest interactions (Smith, 1989) tourism promotes modern values, social progress and cultural evolution. Telfer (2002) highlighted social transformations in rural destinations by indicating declining values of family and other collectiveness and introducing of modern values and institutions similar to Western societies. In a sense, these destinations today suffers tension between what they have understood as modernization and traditionalism and are losing its resilience, an ability to maintain, renew, reorganize social and cultural system functions (Varghese, Krogman, Beckley 
and Nadeau, 2006). The dances in Nepali and Hindi songs and the incipient attitude of peoples are the testimony of lukewarm habits towards traditional culture, religion, customs, rites and rituals which can clearly seen among the youngsters. This has created detachment for the existing culture. There were instances of cocktail celebration of birthday composed of traditional rituals and cake-cutting. Potentially these can also affect the visitor experience and affect the authenticity of the cultural experience.

\section{Towards a Pragmatic Paradigm}

By pragmatic paradigm, I mean location specific, culturally relativist, ecologically conditioned and social setting ingrained paradigm, that is, all ways anthropic as par with the notion of development anthropology that there is no ready-made developmental model (Hirst, Thompson \&Bromely, 2009). I hold the view that development is a dead word, to de/constructed.

Why do I feel so?

Let me answer this via critical evaluation of two development theories of quasidevelopment fragrance -enverionmatalism and sustainable development that came into existence with the disillusionment with modernization theory (Harrison, 2014) and where the offshoot of two very popular notions of tourism-ecotourism and sustainable tourism lies.

I am with Telfer (2015) that like its predecessors, environmentalism too relied on western science but, unlike them, focuses on change away from Western (non-) development to a future where, to some extent, the environmental excesses it has caused can be counteracted. In this sense, it is hard to see environmentalism as a specific paradigm By contrast, sustainable development, which might be described as development that is environmentally, socially and culturally sound, has proved more durable. However, this notion, too, is problematic as term itself can be seen as an oxymoron, involving both sustainability and change (Sharpley, 2015). True, the concept of sustainable development can enable the articulation of specific benchmarks and indicators, but too frequently it remains at the level of rhetoric, and at worst it can be highly ambiguous, a barrier to understanding, and prone to misappropriation, manipulation and "greenwashing" (Mowforth\& Munt 2009; Sharpley 2015).

Clearly, I can reject mainstream development models for these reasons, and posit an alternative. I hold the view that development, in fact, is the problem and not the solution; economics is an obsolete science, and both should be abandoned. Instead, faith should be placed in localized responses and social movements (Rist, 2014). In align with this conscientization, my notion of pragmatic development is built around in these ideas: the interest in alternatives to development, not the interest of alternative development; a fundamental rejection of the classical development paradigm; an interest in local culture and local knowledge; a critical perspective on established 
scientific discourses; and solidarity for pluralistic grassroots movements (Sach, 2010). This emphasizes the profound realization that development must be an indigenous process. The concept of indigenous development per se envisages a perspective in which people living in specific, social, cultural, economic and ecological setting define their own concepts of development definition of relevance and correspondence indigenous circumstances (Berrman, 1994). This means that development policies and practices must identify, nurture and sustain indigenous potential means and resources to express diversity and plurality of social values, cultural institution and identity of each nation and community (Wangoola, 1993)

Under such postulations, pragmatic conceptualization for other tourism models, other forms of tourism development, other tourism practices with another relationship to the environment, host societies, responds to the need of building other tourism models, more sustainable and more ethical (Mowforth\& Munt, 2009) requires a break with the model of mass tourism and to imagine other types of tourism, with another philosophical approach which favors encounter with the host population (De Kadt 1990). My notion of pragmatism concerns a variety of approaches: green tourism, sustainable tourism, ecotourism eco-tourism, agro-tourism, community tourism, ethical tourism. Pragmatic tourism is, thus, synergistically defined as a form of tourism that emphasizes the development of local communities and allows for local residents to have substantial control over, and involvement in; its development and management, and a major proportion of the benefits remain within the community. Beyond the economic issues, pragmatic tourism considers the social and cultural dimensions, the relationship to the environment, the participation of host communities and develop sustainable tourism strategies with more significant economic benefits for the host country. Pragmatic tourism fosters sustainable use and collective responsibility, but it also embraces individual initiatives within the community. With this form of tourism, local residents share the environment and their way of life with visitors, while increasing local income and building local economies. A successful model of pragmatic tourism works with existing community initiatives, utilizes community leaders, and seeks to employ local residents so that income generated from tourism stays in the community and maximizes local sociocultural, ecological and economic benefits.

The three defining pillars of Pragmatic Paradigm include:

\section{Sustainability}

Pragmatic paradigm calls for the establishment of functional solidarity among all the systems that calls respect and preserve all the characteristics of the topology, help residents reclaim historical practices, revitalize productive activities, highlight the ethnic background of the population, and highlight the unique aspects of the 
locality, such as topography, climate, architecture, cuisine and handicrafts. My notion of sustainability entails the community's resilience to maintain, renew, reorganize economic, ecological and socio-cultural system functions that a resilient community is empowered to take control of their own developmental efforts and achieve an accelerated adaptive capacity. In congruent with Farrell and Twing-Ward (2004), within the pragmatic paradigm enhancement of resilience is an adaptive management approach rather than trying to manage tourism through attempting to maintain equilibrium in the constantly changing and evolving world and its disturbances.

\section{Participation}

Within pragmatic paradigm, participation is a right held by all people to engage in society and in the decisions that impact their lives. Participation is, thus, a political endeavor for the mobilization of people to eliminate unjust hierarchies of knowledge, power, and economic distribution. This is not just limited to presence; central elements of participation includes democratic processes, governing accountability and collaborative action, that is, empowerment: whether the voices are heard or not? This perspective identifies the goal of participation as an empowering process for people to handle challenges and influence the direction of their own lives. Participatory processes enable people to see more clearly, and learn from the complexity that they are living and working amid. Through participation people can identify opportunities and strategies for action, and build solidarity to effect change Empowerment participation is when primary stakeholders are capable and willing to initiate the process and take part in the analysis (Rist, 2014). This leads to joint decision making about what should be achieved and how. While outsiders are equal partners in the development effort, the primary stakeholders are primus inter pares, i.e., they are equal partners with a significant say in decisions concerning their lives. Dialogue identifies and analyzes critical issues and an exchange of knowledge and experiences leads to solutions. Ownership and control of the process rest in the hands of the primary stakeholders.

\section{Justice}

In the context of pragmatic development, elements of justice include local ownership, sovereignty of the people and equality and equity and equality in the distribution of the fruits of tourism and development. This pillar emphasizes the need for local ownership so that communities have responsibility and control over their resources in order to benefit themselves. This is based on the philosophy that individuals have a greater incentive to pursue anthropic development practices when resources are locally owned and rejects the right of one person to self-enrichment based on the appropriation of the resources on which another person's survival depends 


\section{Derivation and Conclusion}

Analyzing the discourses that developed in and around tourists-host interaction in these destinations, and their subsequent attempt to modify the objective world, tourism can be seen as an advocate of modernization, and westernization, a vehicle of globalization, which can be understood as diffusion or as a form of social change as the structure and the function of social system are (in the process) modified through innovation, expansion and adoption of new ideas, values, norms and behavior pattern (Kunwar, 2010). When people from two different anthropic environments (the stronger guests and the weaker hosts) encounter, the formal is likely to influence the later. Weaker anthropic environment is likely to emulate stronger anthropic environment and their attitude unfolds through the stage of euphoria, appreciates and shows very much the positive attitude towards stronger anthropic environment. This typificaton and reflexivity are longingly confirmed in the individual's cogency landmarks the construction of incipient reality in a mirror effect which is largely governed by the internal process by which they interpret the world around them and give meaning to their lives.

I am with social constructivists (in Adam \& Sydie, 2002) that people not only encounter, they interpret: they not only respond, they discover and create as well. People seek not merely to know the world, but are driven to understand it and their relationship to it, to their fellowmen and to themselves. People are not caused to act, they act out of choice. People act in accordance with their perception. People create, modify (or ignore) their identities based on what influences them and other, is essentially the product of social interaction. In particular, individual possess a self-concept or images of themselves, that is build up, reinforced or modified in the process of interaction with other members of the society. It is for this reason, the symmetry between objective and subjective reality is never static. Consequently, social change is both likely and unpredictable. The construction of newer reality is, thus, the product of dialectic process which is interactive and inter-subjective, and the process of interaction, in an important way, or at least, of the encounter by the individual in everyday life serve to reaffirm his subjective reality. The reality so constructed is legitimized by symbolically endowed world of meaning. Symbols are a type of logic in use consisting negotiated meaning that people attach to them. People arbitrarily construct the symbols which consist meaning attach to them and study of those symbols helps us to know about that society.

It is with the study of these symbols, this paper has acquired its present shape which in turn, I am hopeful that, functions as a symbol to academia and for the practice of tourism and development. In my introspection and retrospection at this detour, Boorstin's notion of "pseudo-events" (1964) best epitomizes what is happening in and around tourism in these destinations. State it differently; tourism responsible is for 
affecting local identity through the conveyance of expectations. My perspective is that tourists shape the outcome of touristic encounters by giving preference to locals who look and behave in ways that are authentically indigenous or ethnic. What tourists choose to see is, in turn, has been strongly influenced by the marketing efforts of tour operators (Silver, 1993).In the words of Urry (1990, 1996), tourists' stereotypes are transmitted to locals through what he called "the tourist gaze."A simplistic rendering of this perspective is that tourists wield power through the way they look at locals and expect them to appear and behave. In turn, locals acquiesce to the gaze by mirroring back images they hope will please tourists. The long-term implication is that locals will maintain, or at least act out, traditions they are sure will satisfy and attract more tourists. This process which can be referred as what MacCannell (1992) called "reconstructing ethnicity." Indeed, locals have consciously tried to match visitors' expectations of what is authentic, even if the results seem contrived or fake. Within this "playing up", no doubt tourism has become an empowering vehicle of selfrepresentation (Cohen, 1979), "served to reinforce ethnic identity" (Smith, 1982, p. 26) and "a renaissance of native cultures or the recreation of ethnicity" (Van den Berghe, 1994 p. 17)but the same time incurable social consequences have cropped, somewhat like the growth of wheat plant side by side weed blades that needs to be wiped out. Like double- edged sword is cutting down the both way unplanned growth of tourism has cut down the very structure of social values, which constitute indigenous identity and while development of tourism has brought new ways of life, it has ended to disrupt the traditional activities that give meaning to the life of people. In the long run, these consequences can be serious if these destinations are only groomed to appreciate the positive values or the impacts of tourism. Violations of long nurtured social values can cause serious social problems leading to social conflicts and social disorganization (Thapa, 2005). Doubtlessly, tourism may be bound to bear the seeds of social strife if the situation persists.

This is now high time to scrutinize the anomalies in such a way that tourism can be best utilized for the development of these destinations as a whole, before it will be too late. The more the euphoria and cogency developed in the line of west is best persist the more anomalies get strengthened into irreparable damages leaving these destinations as fairy tale to future generation, and tourists too. The present generation will be the cursed upon the future generation and using flattened edge of one's hand against one's forehead has no meaning when it is too late. Culture is the legacy handed down to us and it our moral and ethical responsibility to hand over the same to our future generation. The legacy of human civilization can be bestowed to future generation only when heritage is preserved. Finally what should be understood is that tourist visit theses destinations to experience "newness", not the "sameness". The epitome around which tourists revolve is the heritage, and if they are to be 
develop in exotic line will attack no tourists. The more the heritage remains intact, the more tourists will visit. The more the tourists' visits the more these destinations will prosper all way round. I will not recommend anyone for hybrid chicken and to see Hindi-dance. Will you? It seemed that home-stay program of these destination has the fragrance of pragmatic paradigm in its inception and likely to function more efficiently upon curbing elitism and intra peripheralization as in case of Sirubari and Ghale Gaon and individualization as in case of Bandipur, with the postulates of what I have proposed as pragmatic paradigm at their disposal.

\section{References}

Adams, B. N., \&Sydie, R. A. (2005).Sociological theory. New Delhi, India: Vistar Publication.

Acharya, B.P. \&Halpenny, E. (2017). Sociocultural Sustainability of small tourism enterprises: Observations from Ghalegaon's community based homestays (PDF Download Available). Available from: https://www.researchgate. net/publication/318219474_Sociocultural_Sustainability_of_Small_Tourism_ Enterprises_Observations_from_Ghalegaon's_Community_Based_Homestays [accessed Sep 11, 2017].

Alba-Juez, L. (2009). Perspectives on discourse analysis: Theory and practice. Newcastle: Cambridge Scholars Publishing. Available at: Ebrary [2014-1-27].

Alexander, B. K. (2005). Performance ethnography: The reenacting and inciting of culture. In N. K. Denzin\& Y. S. Lincoln (Eds.), The sage handbook of qualitative research (3rd ed., pp. 411-441). Thousand Oaks, CA: Sage.

Bagni, G. T. (2008). Richard Rorty (1931-2007) and his legacy for mathematics educators. Educational studies in mathematics, 67(1), 1-2.

Bista, D.B. (1967). People of nepal. Kathmandu: Mandala Book point.

Berrman, G.D. (1994). Anthropology development and public policy. In,Occasionalpapers in sociology and anthropology. Journal of the Central Department of sociology and Anthropology, Tribhuvan University, Kirtipur, Kathmandu, 4:1-32

Blaikie,P., Cameron, J. \& Seddon, D. (1980). Nepal in crisis: Growth and stagnation at the periphery. UK: Clarendon $\mathrm{Pr}$

Black, P. (2000). Sex and travel: Making the links. In S. Clift, \& S. Carter (Eds.), Tourism and sex: Culture, commerce, and coercion (pp. 250-264). London and New York: Pinter.

Boorstin, D. J. (1964). The image: A guide to pseudo-events in America. New York, NY: Harper \& Row. 
Burr, V. (2003). Social constructionism. 2. ed. East Sussex: Routledge.

Cohen, E. (1979). A phenomenology of tourist experiences. Sociology, 13(2), 179-201.

Crook, S., Pakulski, J., \& Waters, M. (1992). Postmodernization: Changes in advanced society. London: Sage Publications.

Davis, L. (2010). Advaitavedanta and zenbuddhism: Deconstructive modes of spiritual inquiry. New York, NY: Continuum International Publishing Group.

De Kadt, E., ed. (1979). Tourism: Passport to development? Oxford: Oxford University Press.

Denzin, N. K. \& Lincoln, Y. S. (Eds.). (2005). The Sage handbook of qualitative research ( $3^{\text {rd }}$ ed.). Thousand Oaks, California: Sage Publications.

Dryzek, J. S. (1997). The politics of the earth: Environmental discourses. New York: Oxford University Press.

Erisman, H.M. (1983). Tourism and cultural dependency in theWest Indies. Ann. tour. res. 10:337-61

Feifer, M. (1985). Going places. London: Macmillan

Francise, A. (2001). Modern sociological theory. New York: Oxford University Press.

Gee, J. P. (2005). An introduction to discourse analysis: Theory and method. 2. ed. New York: Routledge.

Harrison, D. (2014). Tourism and development: From development Theory to globalization. In The wiley-blackwell companion to tourism, ed. Hall, M., Lew, A. and Williams, A., 143-154. Oxford: Blackwell.

Hirst, P., Thompson, G. \& Bromley, S. (2009). Globalization in question, 3rd ed. Cambridge: Polity Press.

Jipson, J., \& Paley, N. (2013.) No Style, No Composition, No Judgment. In handbook of the arts in qualitative research: Perspectives, methodologies, Examples, and Issues, 36, 436-450. Thousand Oaks: SAGE Publications.

Jorgensen, M. \& Phillips, L. (2002). Discourse analysis as theory and method. London: Sage. Available at: http://www.rasaneh.org/Images/News/AtachFile/27-31391/FILE634754469767402343.pdf[2017-09-01].

Kunwar, R. R. (2000). Himalayan heritage : a study of society, culture and religion of Nepal. Kathmandu: LaxmiKunwar

Kunwar, R. R. (2010). Tourists and tourism: Science and industry interface. Kathmandu: International School of Tourism and Hotel Management.

Lash, S. \& Urry, J. (1994). Economies of signs and space. London: Sage Publications. 
Luitel, B.C (2016).Transformative educational research: What? why? how?. Closing keynote, In First International Conference on Transformative Research and Sustainable Development, October 21-23, Dhulikhel, Nepal, www.kused.edu. $\mathrm{np} / \mathrm{ter} 2016$.

MacCannell, D. (1976). The tourist: A new theory of the leisure class (1st ed.). New York, NY: Schocken Books.

MacCannell D. (1992). Empty meeting grounds: The tourist papers. New York: Routledge

Mowforth, M. \& Munt, I. (2009). Tourism and sustainability: Development, globalisation and new tourism in the third world. London: Routledge.

Munt, I. (1994). The "other" postmodern tourism: Culture, travel, and the new middle classes. Theory, culture, and society, 11(3),101-123.

Phillips, N. \& Hardy, C. (2002). Discourse analysis: Investigating processes of social Construction.(Sage University Papers Series on Qualitative Methods, Vol. 50). Thousand Oaks, CA: Sage.

Reed R. (1995). Household ethnicity, householdconsumption: commodities and the Guaran'1. Econ. dev. cult. change44:129-45

Regmi, K.D \& Walter, P.G. (2016) Conceptualising host learning in community-based ecotourism homestays. Journal of ecotourism, 15(1), 51-63.

Richards, G. (2001). The development of cultural tourism in Europe. In G. Richards (Ed.), Cultural attractions and europeantourism(pp. 3-30). Oxon: CABI Publishing.

Rist, G. (2014). The history of development: From western origins to global faith, 4th ed. London: Zed Books.

Sachs, W (Eds.). (2010). Development dictionary: A guide to knowledge as power. London and NewYork: Zed Books.

Silver I. (1993). Marketing authenticity in third world countries.In,Ann. tour. res. 20:302-18

Sharpley, R. (2015). Sustainability: A barrier to tourism development? In Tourism and development: Concepts and issues, 2nd ed., ed. Sharpley, R. and Telfer, D., 428-452. Clevedon: Channel View.

Skinner, D. \& Holland, D. (2009). School and the Cultural Reproduction of the Educated Person in a Nepalese Hill Community. In Bhatta, P (Ed.), Education in nepal: Problems, reforms and social change, 333-361. Kathmandu: Martin Chautari 
Sloan, P., Legrand, W. \& Simons-Kaufmann, C. (2014). A survey of social entrepreneurial community-based hospitality and tourism initiatives in developing economies: A new business approach for industry. Worldwide hospitality and tourism themes, 6 (1), 51-61.

Spry, T. (2001).Performing autoethnography: An embodied methodological praxis. Qualitative inquiry, 7 (6), 706-732.

Smith, M. K. (2005). New leisure tourism: Fantasy futures. In D. Buhalis, \& C. Costa (Eds.), New tourism consumers, products, and industry: Present and future issues (pp. 220-227). Oxford: Butterworth-Heinemann.

Telfer, D. (2015). The evolution of tourism and development theory. In Tourism and development: Concepts and issues, 2nd ed., ed. Sharpley, R. and Telfer, D., 31-73. Clevedon: Channel View.

Thapa, R. (2005). Tourist and the locals: Interaction and interpretation, (unpublished master degree thesis), Tribhuwan University.

Thapa, R. (2016). Unleashing Liminalities: An autoethnographic autopsy of identity politics, (unpublished doctoral thesis), Kathmandu University

Uriely, N. (2005). The tourist experience: Conceptual developments. Annals of Tourism Research, 32(1), 199-216.

Urry J. (1990)The tourist gaze: Leisure and travel in contemporary societies. London: Sage

Urry J. (1996). Tourism, culture and social inequality.In The sociology of tourism: Theoretical and empirical investigations, ed. YApostolopoulos, S Leivadi, A Yiannakis, pp. 115-33. New York: Routledge.

Van den Berghe P. (1994). The quest for the other: Ethnic tourism in San Crist'obal, Mexico. Seattle: Univ. Wash. Press

Wangoola. P. (1993). Regaining people's sovereignty. Participatory Development. Infonotes. 3:3

Wearing, S., Stevenson, D. \& Young, T. (2010). Tourist cultures: Identity, place, and the traveller. London: Sage Publications

Zastrow, C. (2009). The Practice of social work: A comprehensive worktext. UK: Cengage Learning. 